\title{
First records of Amphidoma languida and Azadinium dexteroporum (Amphidomataceae, Dinophyceae) from the Irminger Sea off Iceland
}

\author{
URBAN TILLMANN ${ }^{1}$, MARC GOTTSCHLING ${ }^{2}$, ELISABETH NÉZAN ${ }^{3}$ AND BERND KROCK ${ }^{1}$ \\ ${ }^{1}$ Alfred Wegener Institute, Am Handelshafen 12, D-27570 Bremerhaven, Germany, ${ }^{2}$ Department Biologie, Systematische Botanik \\ und Mykologie, GeoBio-Center, Ludwig-Maximilians-Universität München, Menzinger Straße 67, D-80638 München, Germany, \\ ${ }^{3}$ Ifremer, Station de Biologie Marine, Place de la Croix, BP 40537, 29185 Concarneau Cedex, France
}

\begin{abstract}
Species of dinophycean Amphidomataceae are producers of phycotoxins classified as azaspiracids. We provide the first records of two of their constituent species, Amphidoma languida and Azadinium dexteroporum, for the Irminger Sea off Iceland. Morphological examination and molecular characterization, including uncorrected mean pairwise distances between sequences of the Internal Transcribed Spacer (ITS), doubtlessly assigned the sub-Arctic strain 2 A11 to the reference of Amphidoma languida. Strain $2 A 11$ produced $A Z A-38$ and $A Z A-39$, corresponding to the toxin profile described for the type material. The sub-Arctic isolate $1{ }_{12}$ differed significantly in terms of ITS genetic distance $(p=0.04)$ from a Mediterranean Azadinium dexteroporum strain, but our morphological analysis did not reveal any major or stable diagnostic traits between the reference strain of Azadinium dexteroporum and the new strain described here. In contrast to the Mediterranean strain of Azadinium dexteroporum, the sub-Arctic strain ${ }_{1} D_{12}$ did not produce any known azaspiracids. The new records of Amphidoma languida and Azadinium dexteroporum from the Irminger Sea imply an important range extension of the species, formerly known from the northern and eastern Atlantic (Amphidoma languida) and from the Mediterranean area (Azadinium dexteroporum) only. Together with three new species of Azadinium recently described from the same expedition, the results clearly show that the biodiversity of the Amphidomataceae in the sub-Arctic is remarkably large.
\end{abstract}

Keywords: Azadinium, Amphidoma, azaspiracids, Irminger Sea

Submitted 15 January 2015; accepted 17 August 2015

\section{INTRDDUCTION}

It is predicted that climate change will have dramatic consequences for the (sub-)Arctic region, including increased mean temperature and rapid decline of ice cover (Comiso et al., 2008; Screen \& Simmonds, 2012). These environmental alterations have the potential to cause shifts and changes in plankton communities (Wassmann et al., 2011) and, in particular, may expand the distribution of harmful algae bloom (HAB) species into or within the Arctic Sea (Hallegraeff, 2010). However, to fully evaluate any potential future changes in species distribution and community composition, basic information about the occurrence and distribution of species (past and present) is needed.

Starting in the first half of the 19th Century (e.g. Ehrenberg, 1843), there is a long history on plankton surveys in the Arctic seas. Expeditions during the late 19th and early 2oth Century (e.g. Cleve, 1873; Cleve \& Grunow, 1880; Brandt \& Apstein, 1908; Lebour, 1925; Grontved \& Seidenfaden, 1938) resulted

Corresponding author:

U. Tillmann

Email: Urban.Tillmann@awi.de in extensive lists of plankton species, which remain the basis for contemporary taxonomic research in the Arctic. However, most of these studies focused on diatoms and larger dinophytes because of their using plankton nets for collection and light microscopy for observation. With respect to planktonic protists, the recent assessment of the pan-Arctic biodiversity (Poulin et al., 2011) consequently reveals a striking paucity of information about smaller plankton species $(<20 \mu \mathrm{m})$, accounting for less than $20 \%$ of the currently known species from the region.

A bias in the composition of species lists is also obvious for planktonic dinophytes: among about 200 species present in the Arctic Ocean compiled by Okolodkov \& Dodge (1996), more than $40 \%$ belong to three generic lineages (Dinophysis, Protoperidinium, Tripos) of large and conspicuous thecate species. Thus, the biodiversity and distribution of smaller and less conspicuous dinophytes is not fully explored at this moment in time, as it is illustrated by, for example, Azadinium (Amphidomataceae). Driven by the specific search for the planktonic source of azaspiracids (AZAs) (Krock et al., 2009), the taxon was discovered in 2009 with the description of Azadinium spinosum Elbrächter \& Tillmann. This small and inconspicuous species is the nanoplanktonic source of AZA-1, -2, and -33 (Tillmann et al., 
2009, 2012a). Since then, knowledge about the diversity of Azadinium has increased rapidly and today ten species are described (Tillmann et al., 2014). At least two other species of Azadinium also produce AZAs (i.e. Azadinium poporum Tillmann \& Elbrächter: Krock et al., 2012; Azadinium dexteroporum Percopo et Zingone: Percopo et al., 2013). With the description of Amphidoma languida Tillmann, Salas \& Elbrächter, another nanoplanktonic AZA-producing organism of a divergent (but closely related) lineage of Amphidomataceae was recently identified (Tillmann et al., 2012b).

Most species of Azadinium have been initially described from the North Sea (Tillmann et al., 2009, 2010, 2011) but today, multiple records from various parts of the world are available (Akselman \& Negri, 2012; Hernández-Becerril et al., 2012; Potvin et al., 2012; Gu et al., 2013; Luo et al., 2013; Percopo et al., 2013). However, knowledge about Amphidomataceae, and the presence of AZAs, in the (sub-)Arctic is still scarce (Poulin et al., 2011). Azadinium caudatum (Halldal) Nézan \& Chomérat, the largest and most conspicuous species of Azadinium, has initially been described (as Amphidoma caudata) from the northern Norwegian coast in winter (Halldal, 1953). In addition, a species described as Gonyaulax parva Ramsfjell from the central Norwegian Sea towards Iceland (Ramsfjell, 1959) almost certainly is also a species of Azadinium (see discussion in Tillmann et al., 2014), while another species from the Canadian Arctic (Holmes, 1956; Bérard-Therriault et al., 1999) described as Gonyaulax gracilis J. Schiller probably also refers to a species of Azadinium (see discussion in Tillmann et al., 2014).

In 2012, a research cruise to the North Atlantic Ocean near Greenland and Iceland was carried out, and a number of strains of small Amphidomataceae were isolated. In total, cultures of seven different strains were established. Five of these strains representing three new species of Azadinium (Azadinium trinitatum Tillmann \& Nézan, Azadinium cuneatum Tillmann \& Nézan, Azadinium concinnum Tillmann \& Nézan) have been described elsewhere (Tillmann et al., 2014). Here, we present the detailed identification and the AZA toxin profile of the two other strains, which represent the first sub-Arctic records of Amphidoma languida (initially described from the Irish coast: Tillmann et al., 2012b) and Azadinium dexteroporum (previously known from the Mediterranean only: Percopo et al., 2013).

\section{MATERIAL AND METHDDS}

\section{Isolation and cultivation}

Two strains designated as $2 \mathrm{~A}_{11}$ and $1 \mathrm{D}_{12}$ were established from water samples collected between Greenland and Iceland during a cruise aboard the research vessel 'Maria S. Merian' in August 2012 (Figure 1). Strain 1D12 was isolated from the Irminger Sea (Station 526: $64^{\circ} 45.71^{\prime} \mathrm{N} 29^{\circ} 56.74^{\prime} \mathrm{W}$ ), whereas strain $2 \mathrm{~A} 11$ was isolated off the north-west coast of Iceland (Station 532: $65^{\circ} 27.00^{\prime} \mathrm{N} 24^{\circ} 39.00 \mathrm{~W}$ ). Isolation and establishment of clonal strains was performed as described by Tillmann et al. (2014). Established strains were routinely grown at both $10^{\circ} \mathrm{C}$ and $15^{\circ} \mathrm{C}$ in an natural seawater medium prepared with sterile-filtered (0.2 $\mu \mathrm{m}$ VacuCap filters, Pall Life Sciences; Dreieich, Germany) Antarctic seawater (salinity: $34 \mathrm{psu}, \mathrm{pH}$ adjusted to 8.0 ) and enriched with $1 / 10$ strength K-medium (Keller et al., 1987), slightly modified by omitting additive $\mathrm{NH}_{4}^{+}$ions. Strains were grown in $250 \mathrm{ml}$ plastic culture flasks at $15^{\circ} \mathrm{C}$ under a photon flux density of $50 \mu \mathrm{mol} \mathrm{m} \mathrm{m}^{-2} \mathrm{~s}^{-1}$ on a $16: 8 \mathrm{~h}$ light:dark photocycle.

\section{Microscopy}

Light microscopy (LM), including epifluorescence microscopy of 4'-6-diamidino-2-phenylindole (DAPI) stained nuclei, and scanning electron microscopy (SEM) were performed as described by Tillmann et al. (2014). Cell length and width were measured at 1000x microscopic magnification using Zeiss Axiovision software (Zeiss, Germany) and freshly fixed cells (formaldehyde, final concentration $1 \%$ ) of cultures growing at $15^{\circ} \mathrm{C}$.

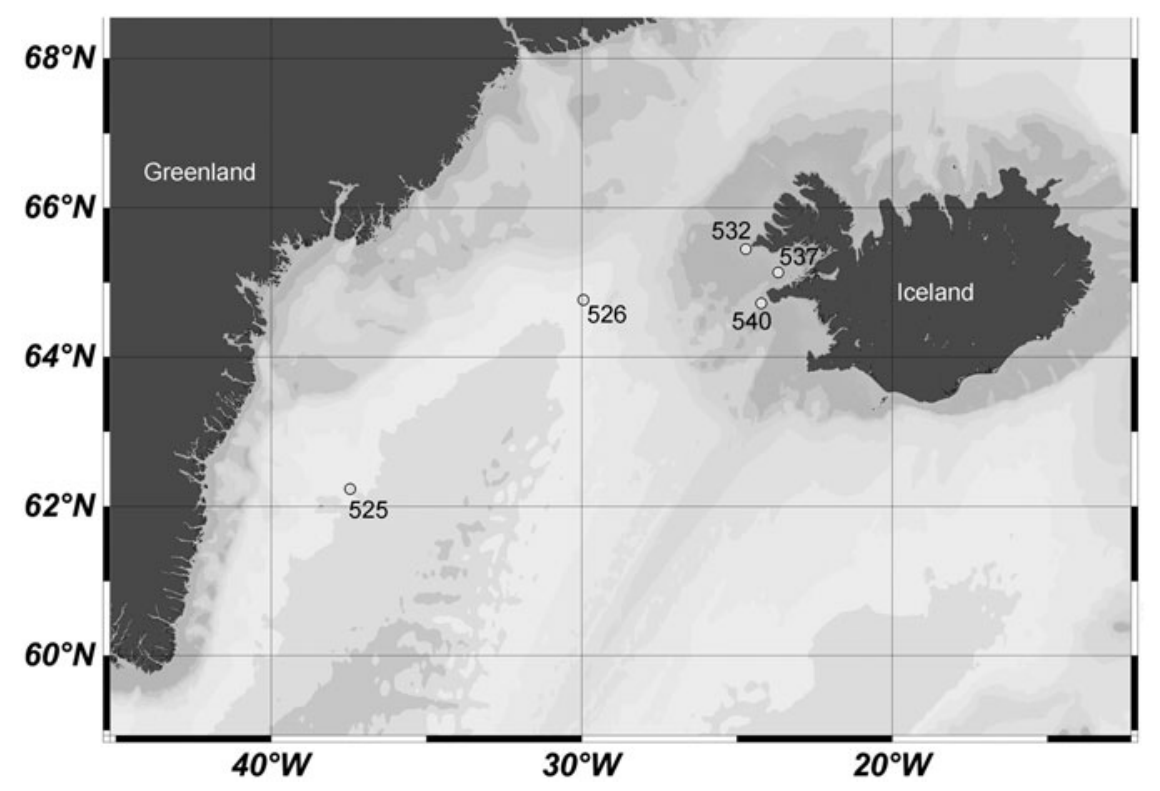

Fig. 1. Selected sampling localities of the 'Maria S. Merian' expedition 2012. 


\section{Toxin analyses}

For each harvest, cell density was determined by settling lugolfixed samples and counting $>800$ cells under an inverted microscope (Axiovert 200M, Zeiss; Göttingen, Germany). Dense cultures (densities ranging from ca. $20-80 \times$ $10^{3}$ cells $\mathrm{ml}^{-1}$ ) were harvested in $4 \times 50 \mathrm{ml}$ centrifuge tubes by centrifugation (Eppendorf 5810R; Hamburg, Germany) at $3220 \mathrm{~g}$ for $10 \mathrm{~min}$. Each four pellets from one harvest were combined in an Eppendorf microtube and again centrifuged (Eppendorf 5415R; Hamburg, Germany) at 16,000 g for $5 \mathrm{~min}$ and stored frozen $\left(-20^{\circ} \mathrm{C}\right)$ until use. The growth and harvest procedure was repeated several times to yield a total number of at least $1.4 \times 10^{8}$ cells. The total volume and number of cells harvested was $4.41,1.48 \times 10^{8}$ cells, and $11.01,1.45 \times 10^{8}$ cells, for Amphidoma languida and Azadinium dexteroporum, respectively.

All harvests of each strain were combined in $2 \mathrm{ml}$ methanol and homogenized with a sonotrode (70 s, 70 cycles, $100 \%$ power; Sonoplus HD 2070, Bandelin, Berlin, Germany). Homogenates were centrifuged $\left(15^{\circ} \mathrm{C}, 3220 \mathrm{~g}, 15 \mathrm{~min}\right.$; Eppendorf 5810 R, Hamburg, Germany). Supernatants were collected and pellets re-extracted twice with $1 \mathrm{ml}$ methanol, each. Combined extracts were reduced in a rotary evaporator (Büchi, Konstanz, Germany) at reduced pressure and $40^{\circ} \mathrm{C}$ water bath temperature to a volume $<0.5 \mathrm{ml}$ and then taken up in acetone to a final volume of $1 \mathrm{ml}$. The extracts were transferred to a $0.45-\mu \mathrm{m}$ pore-size spin-filter (Millipore Ultrafree, Eschborn, Germany) and centrifuged at $800 \mathrm{~g}$ for $30 \mathrm{~s}$ (Eppendorf $5415 \mathrm{R}$ ), with the resulting filtrate being transferred into a liquid chromatography (LC) autosampler vial for LC coupled to tandem mass spectrometry (LC-MS/MS) analysis.

To analyse AZAs, samples were analysed by LC-MS/MS according to the methods described in detail by Tillmann et al. (2009). Selected reaction monitoring experiments were carried out in positive ion mode by selecting the transitions given in Table 1. In addition, precursor ion experiments were performed as described in detail by Tillmann et al. (2014).

\section{Molecular phylogenetic analysis}

DNA isolation, rRNA fragment amplification and sequencing followed standard methods described in Tillmann et al. (2014). Sequences of the new strains were included in an alignment covering the known diversity of the Amphidomataceae. Phylogenetic methods were the same as specified in Tillmann et al. (2014). Uncorrected mean pairwise distances (proportion: p-distances) between sequences of the Internal Transcribed Spacer (ITS) were calculated with PAUP* version 4.ob10 (Swofford, 2002). The sequences were also inspected for possible compensatory base changes that occur when substitutions take place in pairing regions of the molecule folded into a secondary structure (Gottschling \& Plötner, 2004; Thornhill \& Lord, 2010; Kremp et al., 2014).

\section{RESULTS}

\section{Morphological characterization}

Motile cells determined as Azadinium sp. or Amphidoma sp. were observed in concentrated whole water samples at a
Table 1. Mass transitions $\mathrm{m} / \mathrm{z}\left(\mathrm{Q}_{1}>\mathrm{Q}_{3}\right.$ mass) and their respective AZAs.

\begin{tabular}{llr}
\hline $\begin{array}{l}\text { Mass } \\
\text { transition }\end{array}$ & AZA & $\begin{array}{r}\text { Collision } \\
\text { energy } \\
(\mathbf{V})\end{array}$ \\
\hline $716>698$ & AZA-33 & 40 \\
$816>798$ & AZA-34, AZA-39 & 40 \\
$816>348$ & AZA-39 & 70 \\
$828>810$ & AZA-3 & 40 \\
$828>658$ & AZA-3 & 70 \\
$830>812$ & AZA-35, AZA-38 & 40 \\
$830>348$ & AZA-38 & 70 \\
$842>824$ & AZA-1, AZA-6, AZA-40 & 40 \\
$842>672$ & AZA-1 & 70 \\
$842>348$ & AZA-40 & 70 \\
$844>826$ & AZA-4, AZA-5 & 40 \\
$846>828$ & AZA-37 & 40 \\
$846>348$ & AZA-37 & 70 \\
$854>846$ & AZA-41 & 40 \\
$854>670$ & AZA-41 & 70 \\
$856>838$ & AZA-2 & 70 \\
$856>672$ & AZA-2 & 40 \\
$858>840$ & AZA-7, AZA-8, AZA-9, AZA-10, AZA-36 \\
$858>348$ & AZA-36 & 70 \\
$860>842$ & Undescribed & 40 \\
$872>854$ & AZA-11, AZA-12 & 70 \\
\hline & & 40 \\
\hline & & 70 \\
& $>0$
\end{tabular}

number of stations in the Irminger Sea between Greenland and Iceland, and around the north-west coast of Iceland (Figure 1). From this cruise, a total of seven clonal strains were established, two of which were determined as Amphidoma languida (2A11) and Azadinium dexteroporum (1D12), respectively, based on morphology and rRNA sequence comparison.

\section{AMPHIDOMA LANGUIDA 2A11}

Cells of the strain $2 \mathrm{~A} 11$ were easy to identify at low magnification LM because of their characteristic swimming pattern. Cells regularly concentrated at the bottom of the cultivation vessel and exhibited a conspicuous behaviour, in that they normally moved very slowly, and suddenly and irregularly performed jumps. These jumps occurred when cells approached the bottom of the cultivation vessel, or were stimulated by short vibrations of the cultivation vessel.

Cells of Amphidoma languida (strain 2A11) were ovoid to slightly elliptical (Figure $2 \mathrm{~A}-\mathrm{D}$ ), with a conical episome and a distinctly pointed apex. Mean size of recently fomaldehyde-fixed cells was $13.8 \pm 0.9 \mu \mathrm{m}(\min 11.8-\max 16.3, \mathrm{~N}=112)$ in length and $11.8 \pm 1.0 \mu \mathrm{m}(\min 9.6-\max 15.1, N=112)$ in width, resulting in a mean length/width ratio of 1.2. The episome was slightly larger than the hemispherical hyposome, which ended in a pointed antapex (Figure 2D). A large-lobed chloroplast engrossed the entire cell (Figure $2 \mathrm{E}$ ), usually with a single large pyrenoid centrally located in the episome (Figure 2A, C-E). Rarely, cells with two pyrenoids were observed (Figure $2 \mathrm{~F}$ ). As quantified once, 35 of 600 cells $(5.8 \%)$ had two pyrenoids. If two pyrenoids were present, then mostly they were both located in the episome (rarely one of the two pyrenoids was located in the hyposome) and could be of different sizes (Figure $2 \mathrm{G}, \mathrm{H}$ ). The large and spherical to ovoid nucleus was located in the posterior part of the cell (Figure $2 \mathrm{~A}-\mathrm{H}$ ).

The plate formula was determined by SEM as Po, cp, X, 6', oa, 6", 6C, 5(?)S, 6" $6^{\prime \prime \prime} 2^{\prime \prime \prime \prime}$. Arrangement, size and shape of 

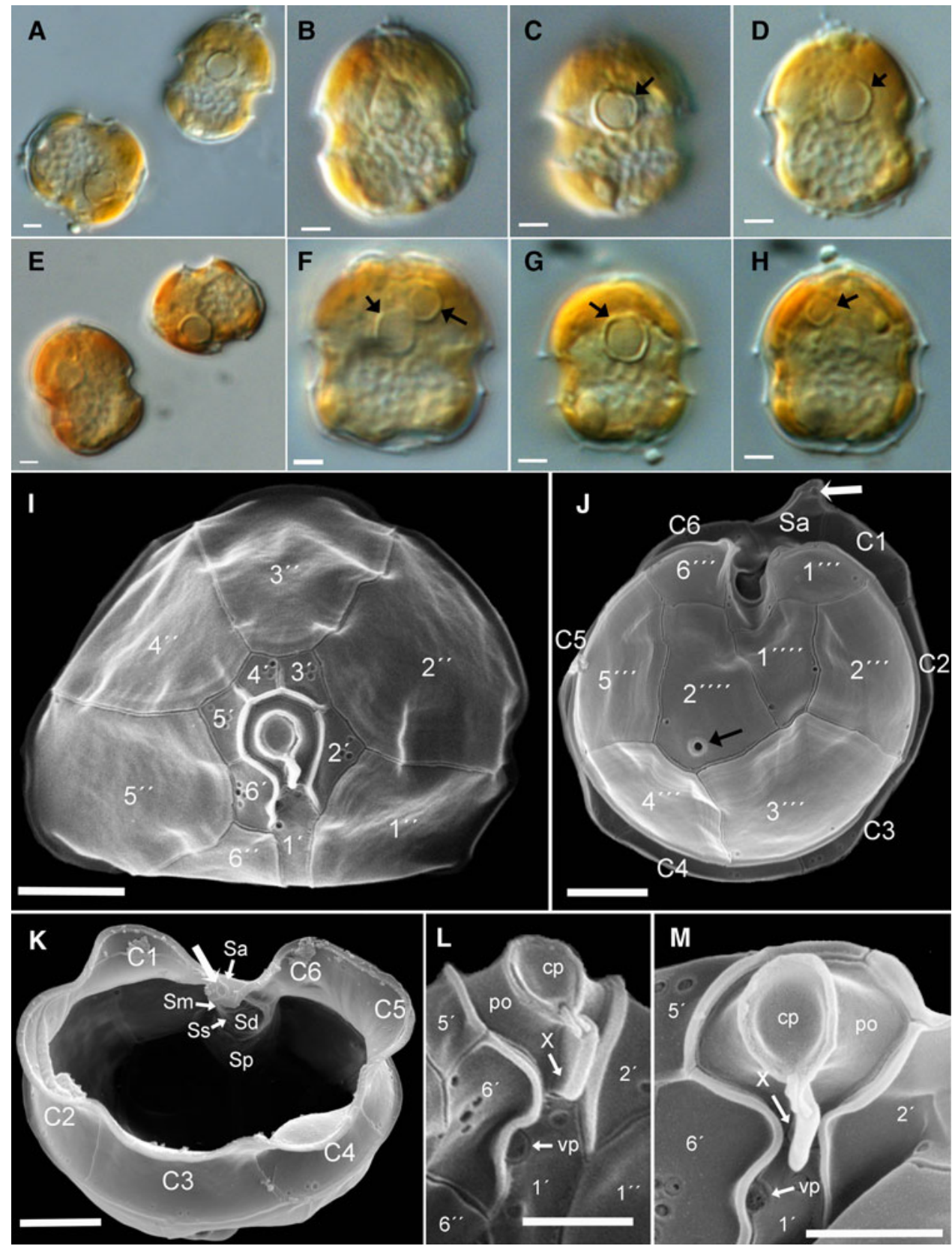

Fig. 2. Amphidoma languida (strain 2A11). (A-H) LM of formalin fixed cells. (A-E) General size and shape. Note the presence of a large pyrenoid in the episome (arrows in C, D). (F-H) Variations in pyrenoid. (F) A broad cell with two pyrenoids (arrows) in the episome. (G, H) Two focal planes of one cell indicating the presence of a large and a small pyrenoid (arrows) in the episome. (I-M) SEM of different cells showing plate pattern of the epitheca (I), hypotheca (J), and of the cingular and sulcal plates in interior view (Sa, anterior sulcal plate; Sm, median sulcal plate; Sd, right sulcal plate; Ss, left sulcal plate; Sp, posterior sulcal plate) (K). (L, M) Cell apex (po, pore plate; cp, cover plate; X, X-plate; vp, ventral pore). Black arrow in J indicates the large antapical pore, white arrows in J and $\mathrm{K}$ the roundish depression on plate Sa. Scale bars: $(A-K)=2 \mu \mathrm{m} ;(L, M)=1 \mu \mathrm{m}$.

specific thecal plates, the location of a ventral pore on plate $1^{\prime}$ and the location of a large antapical pore on plate $2^{\prime \prime \prime \prime}$, as well as the arrangement of small pores on the plates are shown in Figure $2 \mathrm{I}-\mathrm{M}$. On the anterior sulcal plate, a roundish depression was detected at the anterior tip (white arrows in Figure 2J, K). Unlike a pore, the depression did not seem to pass through the thecal plate.

\section{AZADINIUM DEXTEROPORUM $1 \mathrm{D} 12$}

The second strain ${ }_{1} \mathrm{D}_{12}$ was clearly different from Amphidoma, even at low magnification LM, because of its conspicuously smaller size and a different swimming pattern. Cells of strain $1 \mathrm{D}_{12}$ performed sudden jumps as well interrupting a generally calm swimming style, but occasionally they covered longer distances in a faster and jerky mode.

The mean cell size of strain ${ }_{1} \mathrm{D}_{12}$ was $10.5 \pm 0.6 \mu \mathrm{m}$ (min $9.1-\max 12.3, \mathrm{~N}=172$ ) in length and $7.3 \pm 0.6 \mu \mathrm{m}$ (min $6.0-\max 8.9, \mathrm{~N}=172$ ) in width, with a mean length/width ratio of 1.4. The cingulum was very broad and deeply excavated (Figure $3 \mathrm{~A}-\mathrm{H}$ ). A distinct antapical spine was visible in $\mathrm{LM}$ (Figure $3 \mathrm{D}, \mathrm{G}-\mathrm{H}$ ). A presumably single chloroplast 
was parietally arranged and lobed (Figure $3 \mathrm{E}, \mathrm{F}$ ). In cells of a dense culture, the chloroplast was often restricted to the episome, although fluorescence microscopy clearly indicated autofluorescence in both epi- and hyposome (Figure $3 \mathrm{I}-\mathrm{K}$ ). A relatively small pyrenoid visible by its starch cup was present (Figure $3 \mathrm{C}, \mathrm{E}, \mathrm{G}-\mathrm{H}$ ). In addition to the pyrenoid, cells may have a number of large granular structures mainly located in the hyposome, which differed from the pyrenoids in the absence of a clear starch shield covering them (Figure $3 \mathrm{H}$ ). Among 600 cells examined in LM at 1000x magnification, two cells were found with two small pyrenoids in the episome, whereas all other cells had a single pyrenoid (sometime difficult to be identified) consistently located in the episome. A spherical or slightly elongated nucleus was located in the posterior part of the cell. Occasionally (presumably at first stage of cell division), the nucleus distinctly elongated and almost completely filled the cell (Figure $3 \mathrm{I}-\mathrm{K}$ ).

The Kofoidean plate pattern of Po, cp, X, 4', 3a, 6", 6C, $5(?) S, 6^{\prime \prime \prime}, 2^{\prime \prime \prime \prime}$ (Figure 4) conformed with the most common plate pattern of the whole Azadinium genus. The three lateral and dorsal apical plates were small. The sutures of the dorsally located plate $3^{\prime}$ to its neighbouring apical plates were very short so that the epithecal intercalary plates were almost adjacent to the pore plate (Figure $4 \mathrm{D}$, I). Three symmetrically arranged intercalary plates were located dorsally. The outer intercalary plates each bore a group of small pores, whereas plate 2 a invariably was free of pores (Figure $4 \mathrm{~B}-\mathrm{E}$ ). As the most abundant arrangement, the distinctly smaller central intercalary plate 2 a was quadrangular and almost symmetrically located above plate $3^{\prime \prime}$ (Figure $4 \mathrm{~B}, \mathrm{D}$ ). A penta-configuration (i.e. plate $2 \mathrm{a}$ was pentagonal) was at times present with plate $2 \mathrm{a}$ in contact with $3^{\prime \prime}$ and 4 " (Figure $4 \mathrm{C}, \mathrm{E}$ ).

An oval- to teardrop-shaped apical pore was located in the centre of the pore plate $(\mathrm{Po})$ and was connected through a finger-like protrusion with the small X-plate (Figure $4 \mathrm{I}-\mathrm{M}$ ). When seen from inside the cell, the X-plate was small and ovoid (Figure $4 \mathrm{~N}$ ) and was posteriorly tangent but not invading the first apical plate.

As the most characteristic feature, the ventral pore (vp) of Azadinium dexteroporum was located at the distal end of the more-or-less elongated right side of the asymmetric pore plate. In the strain $1 \mathrm{D}_{12}$, a large variability in shape of the pore plate and, thus, in the position of the ventral pore (Figure $4 \mathrm{I}-\mathrm{M}$ ) was found. The vp was displaced posteriorly in varying degrees at the tip of the asymmetric right side of the pore plate but rarely, it was located almost next to the $\mathrm{X}$-plate on the slightly elongated right part of the pore plate (Figure $4 \mathrm{I}$ ). The pore plate was surrounded by a raised proximal rim of the four apical plates all along its posterior margin. This rim continued ventrally along the sutures of $1^{\prime}$ and $4^{\prime}$ bordering the vp (Figure $4 \mathrm{I}-\mathrm{M}$ ), although the rim around the vp varied in thickness and was partially missing occasionally (Figure $4 \mathrm{~J}$ ). The vp itself had a thick outer rim and ranged in outer diameter from 0.26 to $0.46 \mu \mathrm{m}$ (mean: $0.36 \pm$ $0.04 \mu \mathrm{m}, \mathrm{N}=21$ ).

The wide cingulum was descending and displaced by half of its width. Each of the cingular plates exhibited a few scattered pores. On plate $\mathrm{C}_{1}$, and rarely also on plate $\mathrm{C}_{5}$, pores occasionally were enriched in conspicuously arranged fields comprising up to 20 pores (Figure $4 \mathrm{~F}, \mathrm{G}$ ). The sulcus comprised five main plates (Figure $4 \mathrm{H}$ ) in the arrangement typical for Azadinium, with the left sulcal plate (Ss) running along the line from plate $\mathrm{C} 1$ to $\mathrm{C} 6$. Two small plates (the median sulcal plate $(\mathrm{Sm})$ and the right sulcal plate $(\mathrm{Sd})$ ) formed a concave central pocket. An additional structure was occasionally visible above $\mathrm{Sm}$ and Sd (Figure $4 \mathrm{H}$ ). However, it could not be verified whether this represented an additional sulcal platelet, or an internal outgrowth of plate C6 extending to both central sulcal plates. On the hypotheca, the larger of the two antapical plates (i.e. plate $2^{\prime \prime \prime \prime}$ ) exhibited a small spine typically accompanied by a few small pores (Figure ${ }_{4} \mathrm{~F}$ ).

Desmoschisis, as a type of cell division, is described here for the first time for $A$. dexteroporum (Figure 5). The parental theca was shared between the two sister cells, and dividing cells retained their motility throughout the complete mitotic and cytokinetic process. Prior to division, cells increased mainly in width (Figure $5 \mathrm{~A}$ ) and later, plates were separated along a well-defined oblique fission line dividing an anteriosinistral part from a posterio-dextral part (Figure ${ }_{5} \mathrm{~B}-\mathrm{F}$, schematized in Figure $5 \mathrm{G}-\mathrm{H}$ ). Along the fission line, the anterio-
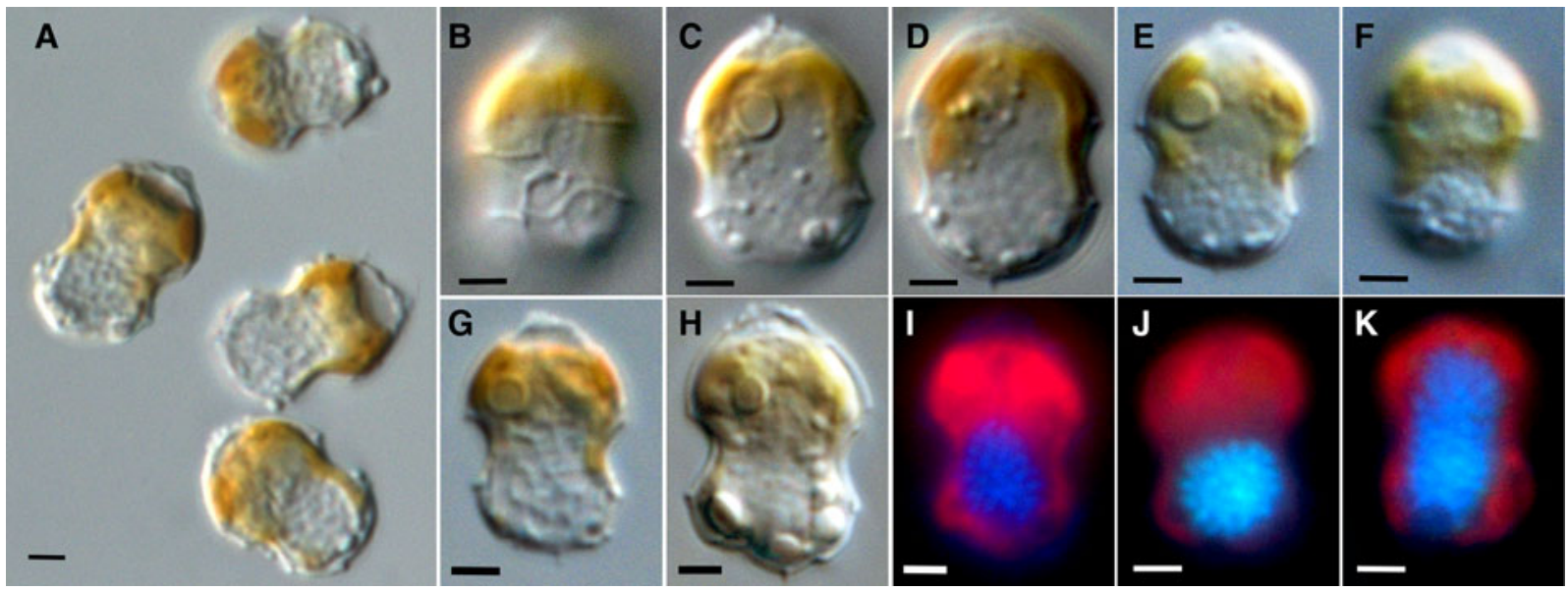

Fig. 3. Azadinium dexteroporum (strain $\left.1 \mathrm{D}_{12}\right)$. LM of formaldehyde-fixed cells. $(\mathrm{A}-\mathrm{H})$ General size and shape. Note the presence of a large pyrenoid in the episome (C, E, G, H) and the presence of an antapical spine (D, G, H). (E, F) Two focal planes of the same cell to illustrate the lobed chloroplast. (H) Cell with a pyrenoid and additional large grains of presumably storage material in the episome. (I-K) Formalin-fixed cells stained with DAPI under UV excitation showing nucleus and chloroplast shape and position. Scale bars $=2 \mu \mathrm{m}$. 


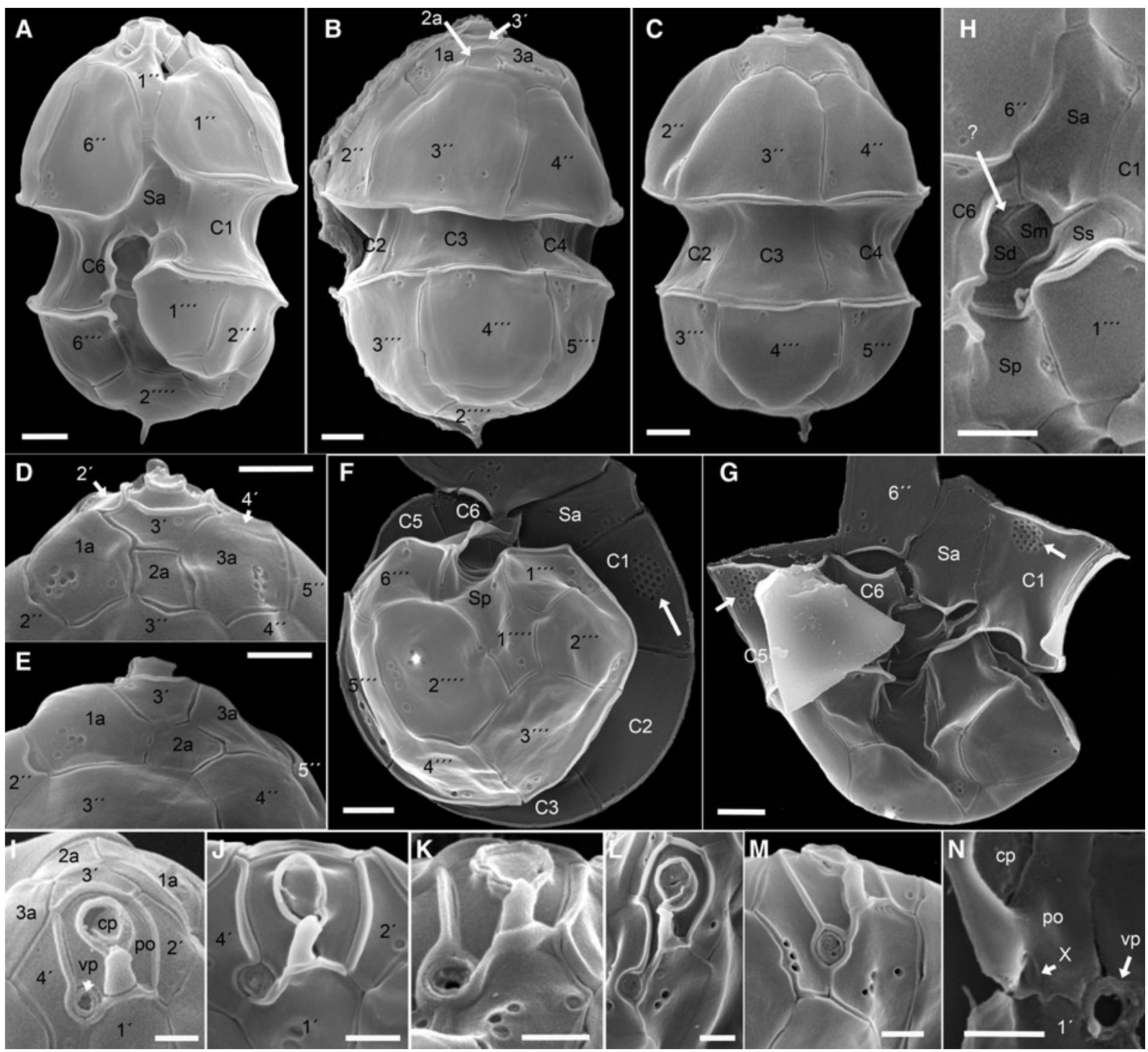

Fig. 4. Azadinium dexteroporum (strain 1D12). SEM of different cells. (A) Ventral view. (B, C) Dorsal view. (D, E) Detailed dorsal view showing plate 2a in quadra- (D) or penta-configuration (E). (F) Antapical view showing hypothecal and cingular plates. Note a large field of scattered pores on the first cingular plate (arrow). (G) Field of pores on $\mathrm{C}_{1}$ and $\mathrm{C}_{5}$ (arrows). (H) Detailed view of the sulcal plates. Note the additional structure (?) visible above Sm and Sd (Sa, anterior sulcal plate; Sm, median sulcal plate; Sd, right sulcal plate; Ss, left sulcal plate; Sp, posterior sulcal plate). (I-N) Detailed views of the apical area (po, pore plate; $c$, cover plate; vp, ventral pore). (N) Internal view of the apical area (X, X-plate). Scale bars: $(A-G)=1 \mu m ;(I-N)=0.5 \mu m$.

sinistral daughter cell (light shaded) inherited all apical plates (including the apical pore complex), the three anterior intercalary plates, the first two precingular plates, the anterior sulcal plate $(\mathrm{Sa})$ and the first four postcingular plates. The posterio-dextral daughter cell (darker shading) received the remaining precingular plates (i.e. $3^{\prime \prime}-6^{\prime \prime}$ ), the posterior sulcal plate $(\mathrm{Sp})$, the fifth and sixth postcingular plates, and the two antapical plates.

Interior views or thecate cells with slightly disarranged plates allowed an identification of the overlap patterns for most plates (Figure $5 \mathrm{G}-\mathrm{H}$ ). Plate $2 \mathrm{a}$ was overlapped by all adjacent plates, and plate C6 was overlapped by the central sulcal plate Sa. As keystone plates (i.e. plates that overlap all adjacent plates) of $A$. dexteroporum, plates $3^{\prime \prime}, \mathrm{C}_{3}$ and $4^{\prime \prime \prime}$ for the precingular, the cingular and the postcingular series were identified, respectively. The course of the fission line followed this plate overlap pattern. In the epitheca, all plates of the posterio-dextral daughter cell overlapped plates of the anterio-sinistral daughter cell (Figure $5 \mathrm{G}$ ). In the hypotheca, plates of the anterio-sinistral half overlapped plates of the posterio-dextral half with one exception: the first antapical plate overlapped plate $1^{\prime \prime \prime}$ of the anterio-sinistral daughter cell (Figure ${ }_{5} \mathrm{H}$ ).

\section{Phylogenetics}

New rRNA sequences were submitted to GenBank and are available as entries $\mathrm{KR}_{3} 62880-\mathrm{KR}_{3} 62890$. The $\mathrm{SSU}+$ ITS + LSU alignment was 4609 bp long and comprised 1813 parsimony informative sites (39\%, mean of 11.62 per operational taxonomic unit). The Amphidomataceae, including species of Amphidoma and Azadinium, were monophyletic (99LBS, 1.0oBPP; Figure 6). The new strains were reliably retrieved (100LBS, 1.0oBPP) with Amphidoma languida (strain 2A11) and Azadinium dexteroporum (strain 1D12), respectively. 

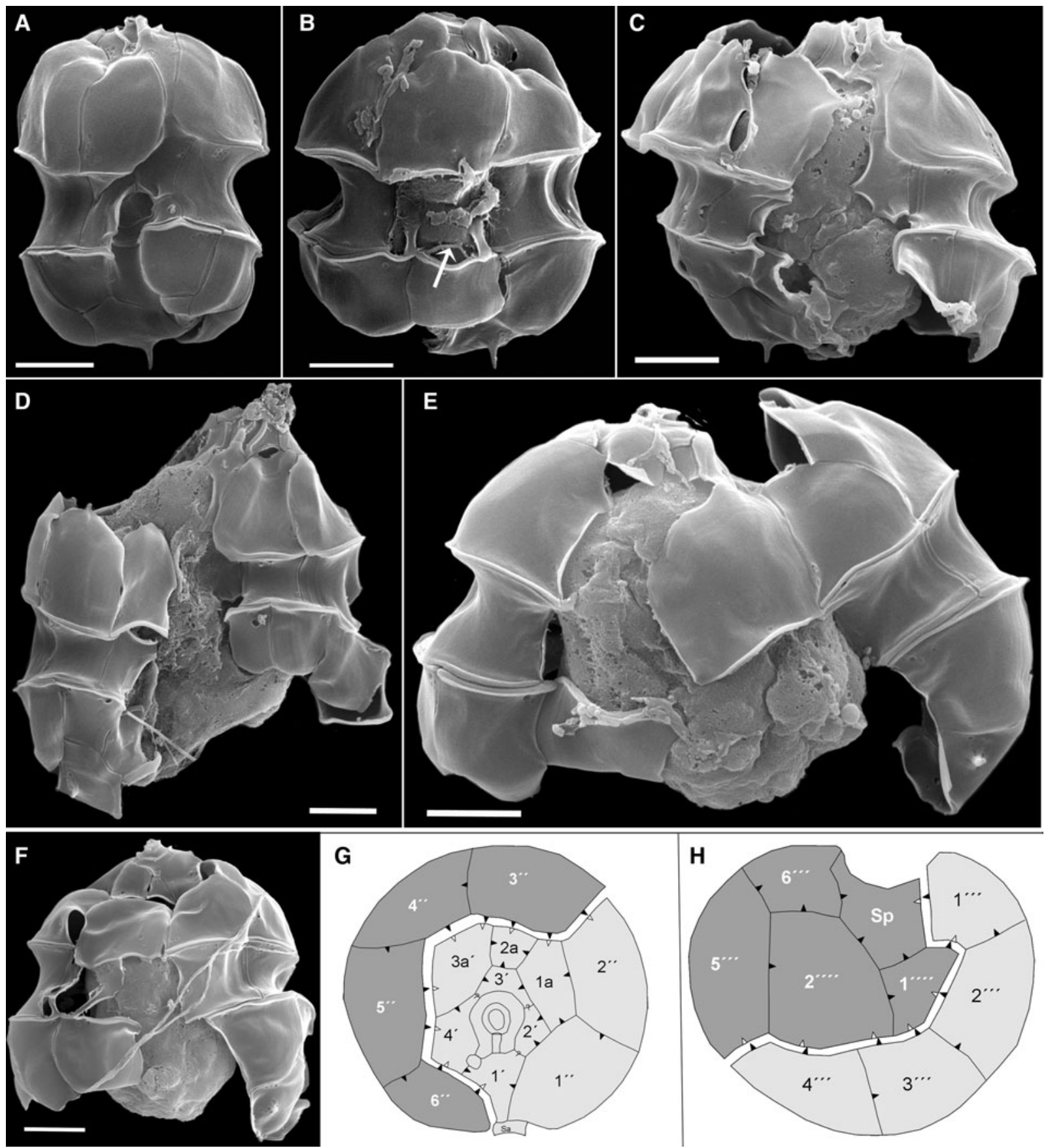

Fig. 5. Azadinium dexteroporum (strain $1 \mathrm{D}_{12}$ ). SEM of different cells. (A) Pre-division cell with a broadened cell width. (B-F) Cells in different stages of cell division in ventral $(C, D)$ or dorsal (B, E, F) view (arrow in (B): indication of dissolution of cingular plate $C_{3}$ ). (G, H) Schematic view of fission line of epitheca $(\mathrm{G})$ and hypotheca $(\mathrm{H})$ separating the anterio-sinistral daughter cell (light shading) and the posterio-dextral daughter cell (darker shading); arrowheads indicate direction of plate overlap, with black symbols at the fission line indicating plate margins overlapping the plate with the corresponding white symbols.? = direction of plate overlap unclear. Scale bars $=2 \mu \mathrm{m}$.

Within strains and species, ITS pairwise distances were low (Table 2), specifically $\sim 0.01$ between the Irish strain SM1 of Amphidoma languida and strain $2 \mathrm{~A} 11$, and $\sim 0.04$ between the Mediterranean strain SZNB-848 of Azadinium dexteroporum and strain $1 \mathrm{D}_{12}$, respectively. All LSU sequences of Amphidoma languida obtained are identical, whereas the LSU sequence of SZNB-848 exhibited seven different positions in comparison to those (identical) of ${ }_{1} \mathrm{D}_{12}$. Compensatory base changes could not be stated, also not for the more divergent strains of Azadinium dexteroporum.

\section{Azaspiracids}

Strain 2A11 (Amphidoma languida) showed AZA cell quotas of 0.8 and $1.5 \mathrm{fg} \mathrm{cell}^{-1}$ for AZA-38 and AZA-39, respectively. In the cell pellet of strain 1D12 (Azadinium dexteroporum), known AZAs were not detected. The limit of detection of AZAs was calculated as $0.007 \mathrm{fg} \mathrm{cell}^{-1}$ for AZA-1. For both strains, precursor scans of the characteristic AZA fragments $\mathrm{m} / \mathrm{z} 348$ and $\mathrm{m} / \mathrm{z} 362$ did not reveal any indication of the presence of yet undescribed variants. 


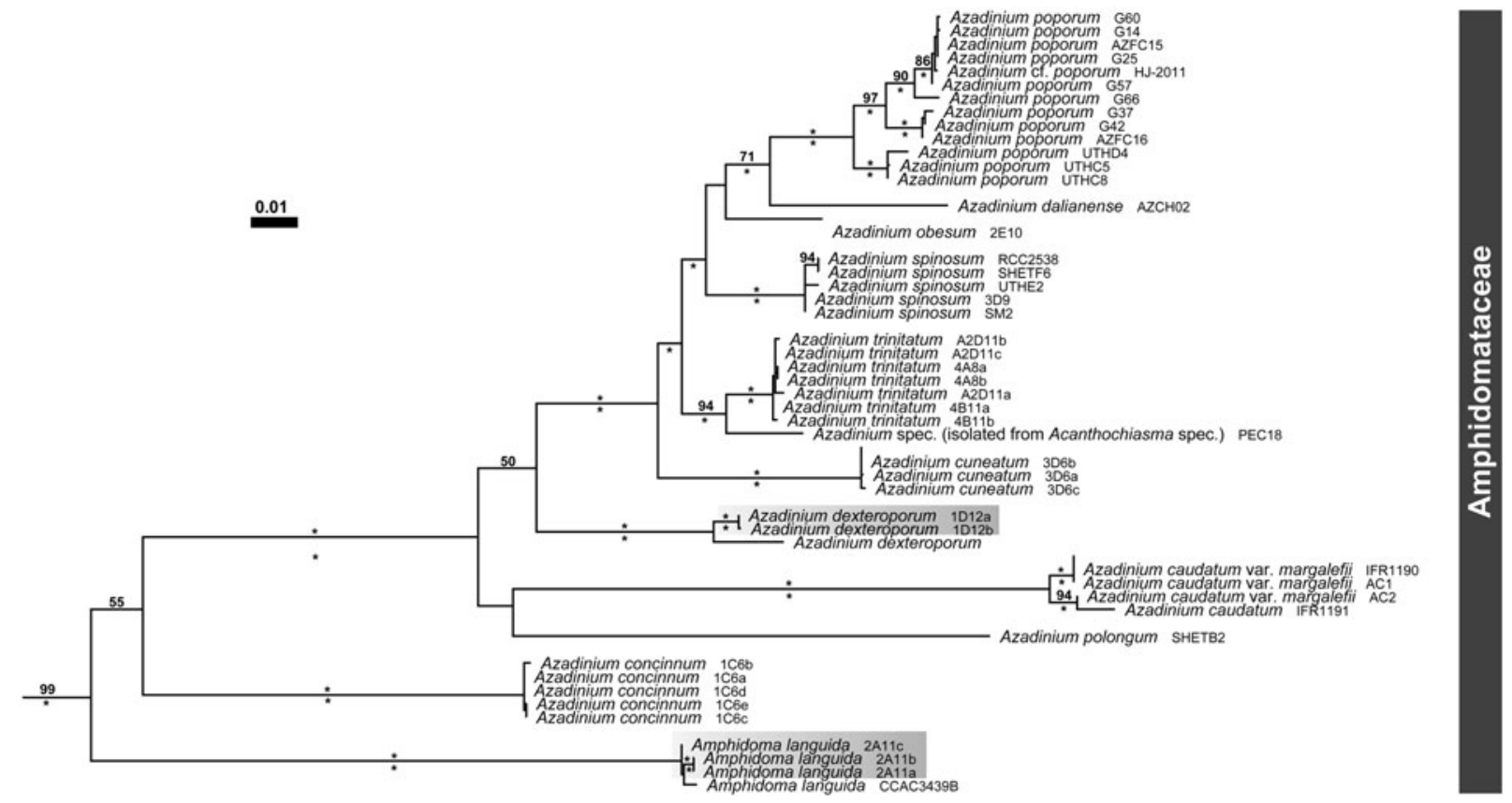

Fig. 6. Maximum likelihood tree $(-\ln =72,424.15)$ of 48 operational taxonomic units assigned to the Amphidomataceae (cut-off from Tillmann et al., 2014, with the outgroup truncated), as inferred from a MAFFT-generated rRNA nucleotide alignment spanning the SSU, ITS and LSU (1813 parsimony informative positions). Branch lengths are drawn to scale, with the scale bar indicating the number of nucleotide substitutions per site. Numbers on branches are statistical support values for the clusters to the right of them (above: ML bootstrap support values, values under 50 are not shown; below: Bayesian posterior probabilities, values under 0.90 are not shown), and asterisks indicate maximal support values. The new sub-Arctic strains are highlighted.

\section{DISCUSSIDN}

The data now available leave no doubt that strain 2 A11 represents the first record of Amphidoma languida from the sub-Arctic. The conspicuous swimming behaviour has been previously described and documented for Amphidoma languida (Tillmann et al., 2012b) and thus, this strain has been expected to represent this particular species since first observation. The specific designation is confirmed by detailed LM and SEM studies: plate formula, arrangement, size and shape of specific thecal plates, the location of a vp on plate $1^{\prime}$ and the location of a large antapical pore on plate $2^{\prime \prime \prime \prime}$, as well as the arrangement of small pores scattered over the plates, correspond to the original description of Amphidoma languida (Tillmann et al., 2012b). The roundish depression on the anterior tip of the anterior sulcal plate has not been explicitly noted for the type material, but it is visible in the original material of strain SM1 (Tillmann et al., 2012a). However, such a depression is not always obvious (or visible) and thus cannot be regarded as a consistent morphological trait.

The sub-Arctic records of Amphidoma languida represent a remarkable range extension of the species. Formerly, it has been described from the Irish coast (Salas et al., 2011) and most probably has been depicted as Amphidoma sp. by Lewis \& Dodge (1990) from material collected in the eastern North Atlantic. In contrast to the shallow coasts of Ireland and the sub-Arctic near Iceland, cells most likely determinable as Amphidoma languida have been observed in SEM from a sample collected at the open West-Indian Ocean as well ( $5^{\circ} 02.4^{\prime} \mathrm{S} \quad 45^{\circ} 16.8^{\prime} \mathrm{E}$; Consuelo Carbonell-Moore, personal communication), indicating a global distribution and broad ecological tolerance of this species.

Molecular phylogenetic data are in agreement with the morphological conclusion with respect to Amphidoma languida. Sequences of the strain $2 \mathrm{~A} 11$ are almost identical to the reference of Amphidoma languida, as inferred from the low ITS pairwise distances, which are in the usual range for the categories 'intragenomic' and individuals of same species' (Litaker et al., 2007). On the other hand, ITS pairwise distances are larger between the reference sequence of Azadinium dexteroporum and the sequences obtained from the new strain described here. They are even larger than between geographic variants of Azadinium poporum ( $\mathrm{p}<$ 0.02: $\mathrm{Gu}$ et al., 2013) or between the two morphotypes of

Table 2. Genetic pairwise p-distances between ITS regions from Amphidoma languida (first three columns) and Azadium dexteroporum.

\begin{tabular}{lrrrr}
\hline & $\begin{array}{r}\text { Amphidoma languida } \\
\text { strain SM1 }\end{array}$ & $\begin{array}{r}\text { 2A11 sample 13-368 } \\
\text { ITS clone 2, 9 }\end{array}$ & $\begin{array}{r}\text { Azadium dexteroporum } \\
\text { SZN-B848 }\end{array}$ & $\begin{array}{r}\text { 1D12 Sample } \\
\mathbf{1 2 - 3 1 6}\end{array}$ \\
\hline 2A11 Sample 13-368 ITS clone 2 & 0.01353 & 0.00000 & - \\
2A11 Sample 13-368 ITS clone 9 & 0.01353 & - & - \\
2A11 Sample 13-368 ITS clone 10 & 0.00846 & - & - & - \\
1D12 Sample 12-316 & - & - & - \\
1D12 Sample 13-133 & -0.00839 & - \\
\hline
\end{tabular}


Azadinium caudatum var. caudatum and Azadinium caudatum var. margalefii (Rampi) Nézan \& Chomérat $(\mathrm{p}=0.023$ : Nézan et al., 2012). A p-distance of 0.04 is set as the threshold for distinguishing species (Litaker et al., 2007), although fixed values can always be not more than approximation for biological phenomena.

Basic differences in the autecology of the Mediterranean and the sub-Arctic strains of Azadinium dexteroporum seem to be present. In the Mediterranean, the species has been identified at water temperatures between $17.8^{\circ} \mathrm{C}$ and $23.8^{\circ} \mathrm{C}$, and the strain in cultivation has not survived at temperatures below $18^{\circ} \mathrm{C}$ (Percopo et al., 2013). In contrast, our strain ${ }_{1} \mathrm{D}_{12}$ has been isolated from water with a temperature of $8^{\circ} \mathrm{C}$ and is now routinely grown in the lab at $10^{\circ} \mathrm{C}$ and $15^{\circ} \mathrm{C}$, respectively. However, our morphological analysis has not revealed diagnostic traits between the reference of Azadinium dexteroporum and the new strains described here, with thecal plate details corresponding to the type material (Percopo et al., 2013).

However, some minor morphological differences between the two strains of Azadinium dexteroporum described in detail so far are worthy of discussion. In sub-Arctic strain ${ }_{1} \mathrm{D}_{12}$, the position of the vp is slightly variable but generally closer to the apical pore plate than it has been reported for the Mediterranean (type) material. Furthermore, we have never observed a pronounced concavity of the median intercalary plate $2 \mathrm{a}$, which has been highlighted as a peculiar feature of the Mediterranean (type) strain (Percopo et al., 2013). In strain $1 D_{12}$, the median intercalary plate is either tetragonal (i.e. in contact with four other epithecal plates) or pentagonal (and in contact with five epithecal plates), but the latter shape has not been reported for Mediterranean Azadinium dexteroporum. Division mode, fission line and plate overlap pattern reported here for the first time for Azadinium dexteroporum exactly resemble the state for the type Azadinium spinosum as described by Tillmann \& Elbrächter (2010, 2013).

Species delimitation in unicellular protists such as the dinophytes is challenging for multiple reasons, such as complex determination procedures (mostly under the microscope only) and uncertainty of morphological diagnostic traits (frequently at high intraspecific variability). It also remains an open question at this moment in time whether the minute differences between the Mediterranean and sub-Arctic strains of Azadinium dexteroporum in terms of morphology, molecular phylogenetics and ecology are consistent and are an expression of biological speciation, or are to be interpreted as intraspecific variability. More comparative studies (both in the field and using cultivated material), and particularly breeding experiments between different strains, are necessary to resolve this problem. Cryptic speciation is not restricted to the Amphidomataceae, but is a great taxonomic challenge also in other dinophyte lineages such as Alexandrium (Kremp et al., 2014) and Scrippsiella (Zinßmeister et al., 2011; Kretschmann et al., 2014, 2015).

The azaspiracid profile of strain $2 \mathrm{~A} 11$ determined as Amphidoma languida with the presence of AZA-38 and AZA-39 is identical to the (type) strain SM1 (Krock et al., 2012), and toxin cell quotas (fg per cell range) are similar for both strains. The absence of AZAs in strain ${ }_{1} \mathrm{D}_{12}$ determined as Azadinium dexteroporum is in contrast to the results of Percopo et al. (2013) reporting from the presence of AZAs in the Mediterranean strain. However, it is known that toxin production can be variable among strains of a single species. Azadinium poporum has been first described as a non-toxigenic species (Tillmann et al., 2011), but produces several different, novel AZAs (Krock et al., 2012) with a high variability within strains. Among a total of 22 strains of Azadinium poporum analysed so far, four strains without any detectable AZAs were found ( $\mathrm{Gu}$ et al., 2013; Krock et al., 2014). Thus, toxin analyses of more strains are needed to evaluate if the presence/absence of AZAs is a consistent phenotypic trait with the potential to differentiate between Mediterranean and sub-Arctic strains of Azadinium dexteroporum.

The new records of Amphidoma languida and Azadinium dexteroporum, together with the description of three new species of Azadinium (Tillmann et al., 2014) from the same expedition to the Irminger Sea, clearly show that the diversity of the Amphidomataceae in the sub-Arctic is large, especially since our presented findings are based on a single cruise and a limited number of stations. The results of studies like the present are needed to complement and broaden a panArctic biodiversity inventory (Poulin et al., 2011).

\section{ACKNDWLEDGEMENTS}

Thanks to Captain Bergmann and the FS Maria S. Merian crew for their assistance and support for the collection of field material. We greatly acknowledge the help of Wolfgang Drebing (AWI) for analyses of azaspiracids. Financial support was provided by the PACES research program of the Alfred Wegener Institute as part of the Helmholtz Foundation initiative in Earth and Environment.

\section{REFERENCES}

Akselman R. and Negri A. (2012) Blooms of Azadinium cf. spinosum Elbrächter et Tillmann (Dinophyceae) in northern shelf waters of Argentina, Southwestern Atlantic. Harmful Algae 19, 30-38.

Bérard-Therriault L., Poulin M. and Bossé L. (1999) Guide d'identification du phytoplancton marin de l'estuaire et du golfe de Saint-Laurent incluant également certaines protozoaires. Publication spéciale canadienne des sciences halieutiques et aquatiques 128, 1-387.

Brandt K. and Apstein C. (1908) Nordisches Plankton. Kiel, Leipzig: Lipsius \& Tischer.

Cleve P.T. (1873) On diatoms of the Arctic Sea. Bihang Kongelige Svenska Vetenskapelige Akademie Handlingar 1, 1-28.

Cleve P.T. and Grunow A. (1880) Beiträge zur Kenntniss der arktischen Diatomeen. Kongiga Svenska Vetenskaps-Akademiens Handlingar 17, $1-122$.

Comiso J.C., Parkinson C.L., Gersten R. and Stock L. (2008) Accelerated decline in the Arctic sea ice cover. Geophysical Research Letters 35, Lo1703.

Ehrenberg C.G. (1843) Über neue Anschauungen des kleinsten nördlichen Polarlebens. Deutsche Akademie der Wissenschaften zu Berlin Monatsberichte 1843, 522-529.

Gottschling M. and Plötner J. (2004) Secondary structure models of the nuclear Internal Transcribed Spacer regions and 5.8S rRNA in Calciodinelloideae (Peridiniaceae) and other dinoflagellates. Nucleic Acids Research 32, 307-315. 
Grontved J. and Seidenfaden G. (1938) The phytoplankton of the waters west of Greenland. Meddelelser om Grønland 82, 1-380.

Gu H., Luo Z., Krock B., Witt M. and Tillmann U. (2013) Morphology, phylogeny and azaspiracid profile of Azadinium poporum (Dinophyceae) from the China Sea. Hamful Algae 21-22, 64-75.

Halldal P. (1953) Phytoplankton investigations from Weather Ship M in the Norwegian Sea, 1948-49. Hvalrådets Skrifter 38, 1-91.

Hallegraeff G.M. (2010) Ocean climate change, phytoplankton community responses, and harmful algal blooms: a formidable predictive challenge. Journal of Phycology 46, 220-235.

Hernández-Becerril D.U., Barón-Campis S.A. and Escobar-Morales S. (2012) A new record of Azadinium spinosum (Dinoflagellata) from the tropical Mexican Pacific. Revista de Biología Marina $y$ Oceanografía 47, 553-557.

Holmes R.W. (1956) The annual cycle of phytoplankton in the Labrador Sea, 1950-1951. Bulletin of the Bingham Oceanographic Collection 16, $1-74$.

Keller M.D., Selvin R.C., Claus W. and Guillard R.R.L. (1987) Media for the culture of oceanic ultraphytoplankton. Journal of Phycology 23, $633-638$.

Kremp A., Tahvanainen P., Litaker W., Krock B., Suikkanen S., Leaw C.P. and Tomas C. (2014) Phylogenetic relationships, morphological variation, and toxin pattern in the Alexandrium ostenfeldii (Dinopyhceae) complex: implications for species boundaries and identities. Journal of Phycology 50, 81-100.

Kretschmann J., Elbrächter M., Zinßmeister C., Söhner S., Kirsch M., Kusber W.-H. and Gottschling M. (2015) Taxonomic clarification of the dinophyte Peridinium acuminatum Ehrenb., $\equiv$ Scrippsiella acuminata comb. nov. (Thoracosphaeraceae, Peridiniales). Phytotaxa 220, $239-256$.

Kretschmann J., Zinßmeister C. and Gottschling M. (2014) Taxonomic clarification of the dinophyte Rhabdosphaera erinaceus Kamptner, $\equiv$ Scrippsiella erinaceus comb. nov. Thoracosphaeraceae, Peridiniales. Systematics and Biodiversity 12, 393-404.

Krock B., Tillmann U., John U. and Cembella A.D. (2009) Characterization of azaspiracids in plankton size-fractions and isolation of an azaspiracid-producing dinoflagellate from the North Sea. Harmful Algae 8, 254-263.

Krock B., Tillmann U., Voß D., Koch B.P., Salas R., Witt M., Potvin E. and Jeong H.J. (2012) New azaspiracids in Amphidomataceae (Dinophyceae): proposed structures. Toxicon 60, 830-839.

Krock B., Tillmann U., Witt M. and Gu H. (2014) Azaspiracid variability of Azadinium poporum (Dinophyceae) from the China Sea. Harmful Algae 36, 22-28.

Lebour M.V. (1925) The dinoflagellates of the northern seas. Plymouth: Marine Biological Association of the UK.

Lewis J. and Dodge J.D. (1990) The use of the SEM in dinoflagellate taxonomy. In Claugher D. (ed.) Scanning electron microscopy in Taxonomy and functional morphology, Special Vol. 41. Oxford: Clarendon Press, The Systematics Association, pp. 125-148.

Litaker R.W., Vandersea M.W., Kibler S.R., Reece K.S., Stokes N.A., Lutzoni F.M., Yonish B.A., West M.A., Black M.N.D. and Tester P.A. (2007) Recognizing dinoflagellate species using ITS rDNA sequences. Journal of Phycology 43, 344-355.

Luo Z., Gu H., Krock B. and Tillmann U. (2013) Azadinium dalianense, a new dinoflagellate from the Yellow Sea, China. Phycologia 52, $625-636$

Nézan E., Tillmann U., Bilien G., Boulben S., Chèze K., Zentz F., Salas R. and Chomérat N. (2012) Taxonomic revision of the dinoflagellate Amphidoma caudata: transfer to the genus Azadinium (Dinophyceae) and proposal of two varieties, based on morphological and molecular phylogenetic analyses. Journal of Phycology 48, 925-939.

Okolodkov Y.B. and Dodge J.D. (1996) Biodiversity and biogeography of planktonic dinoflagellates in the Arctic Ocean. Journal of Experimental Marine Biology and Ecology 202, 19-27.

Percopo I., Siano R., Rossi R., Soprano V., Sarno D. and Zingone A. (2013) A new potentially toxic Azadinium species (Dinophyceae) from the Mediterranean Sea, A. dexteroporum sp. nov. Journal of Phycology 49, 950-966.

Potvin E., Jeong H.J., Kang N.S.T., Tillmann U. and Krock B. (2012) First report of the photosynthetic dinoflagellate genus Azadinium in the Pacific Ocean: morphology and molecular characterization of Azadinium cf. poporum. Journal of Eukaryotic Microbiology 59, 145-156.

Poulin M., Daugbjerg N., Gradinger R., Ilyash L., Ratkova T. and von Quillfeldt C. (2011) The pan-Arctic biodiversity of marine pelagic and sea-ice unicellular eukaryotes: a first-attempt assessment. Marine Biodiversity 41, 13-28.

Ramsfjell E. (1959) Two new phytoplankton species from the Norwegian Sea, the diatom Coscinosira poroseriata, and the dinoflagellate Gonyaulax parva. Nytt Magasin for Botanikk 7, 175-177.

Salas R., Tillmann U., John U., Kilcoyne J., Burson A., Cantwell C., Hess P., Jauffrais T. and Silke J. (2011) The role of Azadinium spinosum (Dinophyceae) in the production of Azasdpiracid Shellfish Poisoning in mussels. Harmful Algae 10, 774-783.

Screen J.A. and Simmonds I. (2012) The central role of diminishing sea ice in recent Arctic temperature amplification. Nature 464, $1334-1337$

Swofford D.L. (2002) PAUP*. Phylogenetic analysis using parsimony ( ${ }^{*}$ and other methods), Version 4. Sunderland, MA: Sinauer Associates.

Thornhill D.J. and Lord J.B. (2010) Secondary structure models for the Internal Transcribed Spacer (ITS) region 1 from symbiotic dinoflagellates. Protist 161, 434-451.

Tillmann U. and Elbrächter M. (2010) Plate overlap pattern of Azadinium spinosum Elbrächter et Tillmann (Dinophyceae), the newly discovered primary source of azaspiracid toxins. In Ho K.C., Zhou M.J. and Qi Y.Z. (eds) Proceedings of the 13th International Conference on Harmful Algae. Hong Kong: Environmental Publication house, pp. $42-44$.

Tillmann U. and Elbrächter M. (2013) Cell division in Azadinium spinosum (Dinophyceae). Botanica Marina 56, 399-408.

Tillmann U., Elbrächter M., Krock B., John U. and Cembella A. (2009) Azadinium spinosum gen. et sp. nov. (Dinophyceae) identified as a primary producer of azaspiracid toxins. European Journal of Phycology 44, 63-79.

Tillmann U., Elbrächter M., John U., Krock B. and Cembella A. (2010) Azadinium obesum (Dinophyceae), a new nontoxic species in the genus that can produce azaspiracid toxins. Phycologia 49, $169-182$.

Tillmann U., Elbrächter M., John U. and Krock B. (2011) A new nontoxic species in the dinoflagellate genus Azadinium: A. poporum sp. nov. European Journal of Phycology 46, 74-87.

Tillmann U., Gottschling M., Nézan E., Krock B. and Bilien G. (2014) Morphological and molecular characterization of three new Azadinium species (Amphidomataceae, Dinophyceae) from the Irminger Sea. Protist 165, 417-444.

Tillmann U., Söhner S., Nézan E. and Krock B. (2012a) First record of Azadinium from the Shetland Islands including the description of $A$. polongum sp. nov. Harmful Algae 20, 142-155.

Tillmann U., Salas R., Gottschling M., Krock B., O’Driscoll D. and Elbrächter M. (2012b) Amphidoma languida sp. nov. (Dinophyceae) 
reveals a close relationship between Amphidoma and Azadinium. Protist 163, 701-719.

Wassmann P., Duarte C.M., Agustí S. and Sejr M.K. (2011) Footprints of climate change in the Arctic marine ecosystem. Global Change Biology 17, 1235-1249.

and

Zinßmeister C., Söhner S., Facher E., Kirsch M., Meier K.J.S. and Gottschling M. (2011) Catch me if you can: the taxonomic identity of Scrippsiella trochoidea (F. Stein) A.R. Loebl (Thoracospaeraceae, Dinophyceae). Systematics and Biodiversity 9, 145-157.

Correspondence should be addressed to:

U. Tillmann

Alfred Wegener Institute for Polar and Marine Research Am Handelshafen 12, D-27570 Bremerhaven, Germany email: Urban.Tillmann@awi.de 